
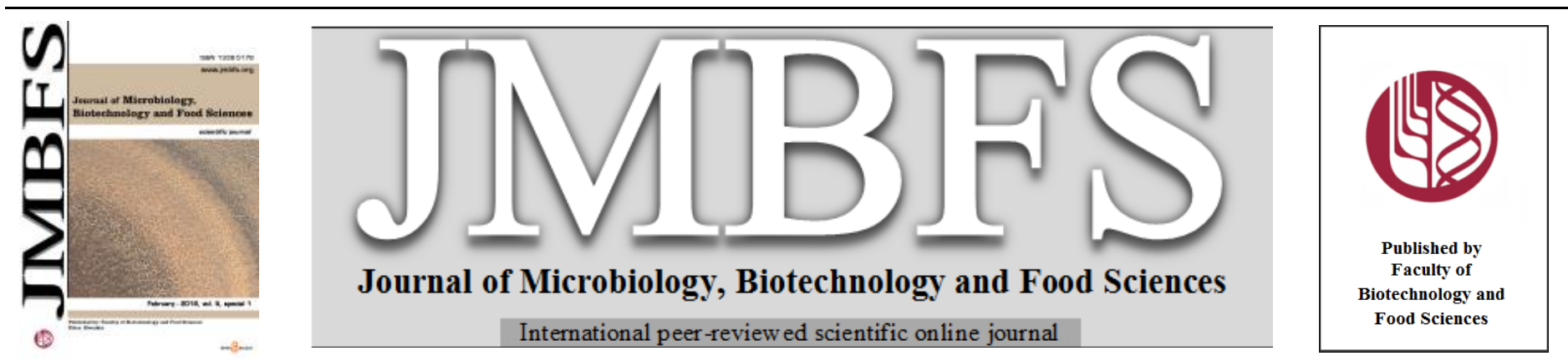

\title{
DETERMINING THE RELATIONSHIP BETWEEN PARAMETERS OF TEXTURE AND CHEMICAL COMPOSITION OF HIGHLY-EFFICIENT SMOKED SIRLOINS
}

\author{
Mariusz Rudy*, Magdalena Marchel, Paulina Duma \\ Address(es): dr hab. inż. prof. UR Mariusz Rudy, \\ Department of Processing and Agricultural Commodities University of Rzeszow Faculty of Biology and Agriculture, ul. Zelwerowicza 4/D9-260, 35-601 Rzeszow, \\ Poland.
}

*Corresponding author: mrudy@ur.edu.pl

doi: 10.15414/jmbfs.2016.5.special1.1-3

\section{ARTICLE INFO}

Received 15. 12. 2015

Revised 20.1.2016

Accepted 22. 1. 2016

Published 8. 2. 2016

\section{Regular article}

open 2 ACcess

\section{ABSTRACT}

Food texture can be assessed by organoleptic and instrumental methods or using both methods simultaneously. The sensory assessment should be supplemented by objective methods of the instrumental analysis, which are based on the measurement of physical features. In this connection the aim of the research was to analyze the relationship between instrumentally measured parameters of texture of highlyefficient smoked sirloins and the marked features in the products such as: the content of protein, fat, water and shear force. Studies were conducted on 120 highly-efficient smoked sirloins (the Sopocka Sirloin) which were bought in one shop of a popular chain of shops located in Rzeszów. Texture parameters of smoked sirloins were marked instrumentally using the texture profile analysis (TPA) conducted by texturometer Texture Analyser - CT3 - 25 Brookfield company with the attachment made by a cone of about $30 \mathrm{~mm}$ in diameter, about $36 \mathrm{~mm}$ long and of the angle of $60^{\circ}$. Next marking of chemical composition was conducted using the analyzer of chemical composition NIR - FoodCheck (Bruins company). There was also conducted the measurement of shear force value was carried out using Warner - Bratzler shear device. Relationships between analysed parameters were set by calculating of cofactors of the Pearson's line correlation.

Keywords: Highly-efficient smoked sirloins, texture, chemical composition, correlation coefficients

\section{INTRODUCTION}

One of quality factors of a meat product is its texture which is defined as a whole of mechanical, geometrical and superficial features perceived by mechanical, tactual, and sometimes also by visual and auditory receptors. It is mainly shaped during production of a given food. Superficial features of texture of meat products usually concern sensations caused by the presence of water and/or fat in the product and by the way of their release from test tube. Here the following terms can be singled out: oily, greasy and fatty consistencies (Juszczak, 2005; PN-ISO 11036, 1999).

Food texture can be assessed by organoleptic and instrumental methods (Szczepańska and Dolik, 2012) or using both methods simultaneously (Marzec, $\mathbf{2 0 0 8 a}, \mathbf{b})$. Sensory assessment is extremely essential, but it is often burdened with a mistake resulting from subjective perception of many features by those who make assessment. Moreover, the assessment demands training of assessing team and ensuring suitable conditions of the assessment. That is why the sensory assessment should be supplemented by objective methods of the instrumental analysis, which are based on the measurement of physical features. Thus instrumental methods are increasingly often used in laboratories and industry. The advantages of their usage are: low costs, higher speed, repeatability of obtained results and the independence of values of these results from the psychophysical state of people who make the assessment or from the place where the research is carried out (Szczepańska and Dolik, 2012). The majority of instrumental methods are based on mechanical tests which include measurements of parameters of foods resistance to forces which act on them. The most common method used to assess the texture is the TPA test (profile analysis of texture). It is one of the methods that stimulate conditions the sample in the oral cavity is exposed to (Bourne, 2002). Other methods often used to assess that feature are the Kramer's and Warner-Bratzler's tests (the measure of cutting strength values) (Marzec, 2008a; Guzek et al., 2013).

The analysis of texture of meat and meat products is most often carried out on the basis of the measure of deformations existing during sample pressing, which also allows determining of such parameters as: hardness, springiness, chewiness or gumminess (Ostoja and Cierach, 2001; Caine et al., 2003; Chang et al., 2010). Hardness is the essential force in order to reach a required deformation, resilience is the speed of returning from the deformed state to the initial state. Chewiness is the energy necessary to grind down products of stable consistency, and gumminess is energy necessary to plasticize a piece of meat to the state which enables its swallowing. (Chang et al., 2010). Caine et al. (2003) and Ruiz de Huidobro et al. (2005) observed that parameters of TPA test indicate an essential correlation with organoleptic assessment and with results of measurements of cutting strength values, determined by the Warner - Bratzler test. Also the texture of meat products depends on, among other things, chemical composition (and/or on the recipe) which is characterized by a given product (Makala and Olkiewicz, 1999; Dolata, 2001; Żochowska-Kujawska et al., 2010).

In this connection the aim of the research was to analyze the relationship between instrumentally measured parameters of texture of highly-efficient smoked sirloins and the marked features in the products such as: the content of protein, fat, water and shear force.

\section{MATERIAL AND METHODS}

Studies were conducted on 120 highly-efficient smoked sirloins (the Sopocka Sirloin) which were bought in one shop of a popular chain of shops located in Rzeszów. Meat products were kept in cooling conditions at the temperature of about $4^{\circ} \mathrm{C}$ till the time of taking measurements. In the Laboratory of the Department of Processing and Agricultural Commodities of Rzeszów University, from each piece, there were cut out 3 samples in the shape of a cube of sides of $30 \mathrm{~mm}$ in order to determine the parameters of texture of studied material.

Texture parameters of smoked sirloins were marked instrumentally using the texture profile analysis (TPA) conducted by texturometer Texture Analyser CT3 - 25 Brookfield company with the attachment made by a cone of about 30 $\mathrm{mm}$ in diameter, about $36 \mathrm{~mm}$ long and of the angle of $60^{\circ}$. There was conducted a test of double pressing of samples to $50 \%$ of their height. The speed of roller during the test was $2 \mathrm{~mm} . \mathrm{s}^{-1}$, whereas the break between pressings was $2 \mathrm{~s}$. The following parameters of texture were measured using the software Texture Pro CT: hardness, adhesiveness, cohesiveness, springiness, gumminess, chewiness and resilience. During serial measurements all texture parameters were counted automatically. 
The next stage of research was the determination of chemical composition of smoked sirloins. For this purpose particular samples of material destined for studies were ground three times in the meat grinder using the net whose holes diameter was 4,0 $\mathrm{mm}$. Next marking of chemical composition was conducted using the analyzer of chemical composition NIR - FoodCheck (Bruins company). It is a computer-controlled spectrophotometer operating in the range of waves of $730-1100 \mathrm{~nm}$

There was also conducted the measurement of shear force value was carried out using Warner - Bratzler shear device. The measurement was conducted on smoked sirloin samples cut out by cork borer of $1 \mathrm{~cm}$ in diameter (in the shape of roller). The samples prepared in this way were placed on knives of a fragility gauge and next the value of pressing strength $\left(\mathrm{kg} / \mathrm{cm}^{2}\right)$ necessary to cut the sample was registered. The mean value of three consecutive measurements was accepted as the final result of of measurement for each smoked bacon samples.

All obtained results were classified and analysed by statistical - mathematic calculation. Straight correlations coefficients between chosen features were placed in tables. Statistical calculation was done based on the STATISTICA PL software, version 10. Relationships between analysed parameters were set by calculating of cofactors of the Pearson's line correlation. The strength of the compound was descriptively determined, depending on absolute values of correlation cofactors as follows (Górecki, 2011)

$0<\mathrm{r}<0.3$ - weak degree of correlation,

$0.3 \leq \mathrm{r}<0.5-$ medium degree of correlation

$0.5 \leq \mathrm{r}<0.7-$ significant degree of correlation

$0.7 \leq \mathrm{r}<0.9$ - high degree of correlation,

$r \geq 0.9$ - very high degree of correlation,

$r=1-$ total correlation.

\section{RESULTS AND DISCUSSION}

In table 1 were placed correlation cofactors between instrumentally analysed parameters of texture of highly-efficient smoked sirloins. From that data it turns out that there exist statistically significant relationships between studied features For example, there was observed a very high and positive relation between hardness 2 a was noticed: hardness $1(\mathrm{r}=0.945)$, gumminess $(\mathrm{r}=0.965)$ and chewiness $(r=0.952)$. Also it was stated that statistically significant relations between gumminess, and chewiness $(\mathrm{r}=0.994)$, hardness $2(\mathrm{r}=0.965)$, hardness $1(\mathrm{r}=0.895)$, springiness $(\mathrm{r}=0.584)$ and between chewiness, and hardness $1(\mathrm{r}=$ 0.890). Also significant medium degree of correlation was stated between hardness 1 and such features as: chewiness $(r=0.890)$, springiness $(r=0.521)$ and between resilience a: hardness $2(r=0.582)$, adhesiveness $(r=0.432)$ and chewiness $(\mathrm{r}=0.638)$. The mentioned correlation coeficients are positive and statistically significant $(\mathrm{p} \leq 0.05)$. Also from the data presented in table 1 it results that there exists statistically significant negative relation between adhesiveness and resilience $(\mathrm{r}=-0.325)$

Biller (2013) analyzing the relationship between specific instrumental physico chemical parameters of model meat products and their shear force observed that there are statistically significant dependencies, but only between some of these features indicated in the raw material and they are mainly related to its type. Also this author stated that studies of relations between these features characterizing such a raw product and the product subjected to roasting allow making products of known and controlled features of colour and texture.

According to Duda (1998) meat and its products belong to such a food group where the texture is a predominant quality characteristic beside the taste. That is why the meat industry tries to find new possibilities of its improvement. Mos frequently functional additions of the plant, animal, or even microbiological origin are used. First of all, they allow shaping and stabilizing such texture features as: consistency, flexibility and block tying and they may result in texture improvement of meat of lower technological usefulness of the type PSE (Nielsen, 1995; Zhu., 1995). Cierach and Gral (2005) carried out the texture analysis of the Żywiecka Sausage and rolled bacon with addition of transglutaminase. These authors showed that addition of that substance to meat products resulted in essential changes of texture parameters values, causing the increase of strength of tearing of slice and hardness.

Dolatowski et al. (2003) studied rheological and sensory properties of mode meat - fat product, which was produced from beef and pork fat with diversified addition of oat seed after the hydrothermal processing. Those authors stated statistically significant influence on the way of preparing oat seed (type of solution) and the size of addition on that texture parameters of those products, such as: hardness, gumminess, or cohesion (correlation coefficient $0.93 \geq r \geq 0.68$ ).

Dolik and Kubiak (2013) analysing the results from instrumental measurements of texture profile indicated that it is a universal test which allows conducting marking of selected texture parameters of different foodstuffs in a short time and it perfectly complements sensory tests in this respect.

Table 1 Correlation coefficients between instrumentally analysed parameters of smoked sirloins texture

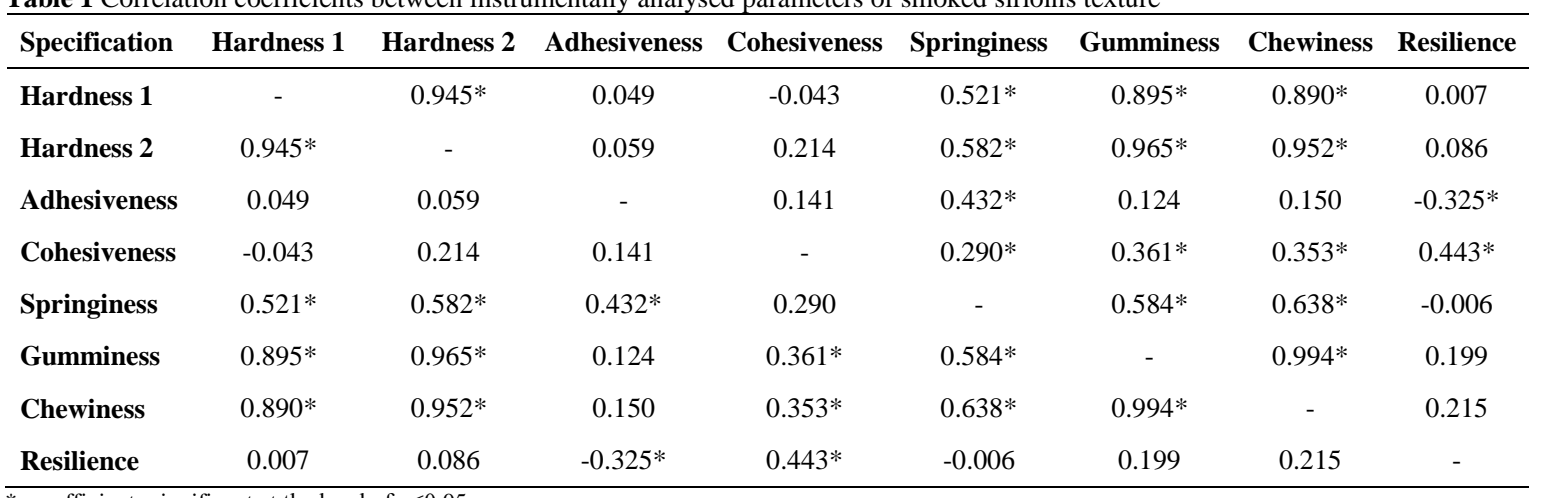

*- coefficients significant at the level of $\mathrm{p} \leq 0.05$

of their quality either and unfavourably influences rheological values of fillings and texture of ready products.

In table 2 there were placed coefficient correlations between instrumentally analysed texture parameters, and chemical composition and shear force of smoked sirloins. These data shows that between these characteristics statistically significant correlations are found only at the medium level. For example, an increase in water content in studied products will cause a decrease of their cohesion $(r=-0.446)$, gumminess $(r=-0.378)$, chewiness $(r=-0.354)$ and hardness in lower degree $(\mathrm{r}=-0.260)$. Also an increase of protein content in smoked sirloins will cause a decrease of values of such parameters of their texture as: cohesion $(r=-0.447)$, gumminess $(r=-0.317)$ and chewiness $(r=$ 0.297). However, an increase in the level of fat in these products will result in an increase in their cohesion $(r=0.487)$, gumminess $(r=0.389)$, chewiness $(r=$ $0.367)$ and hardness $(r=0.255)$, whereas springiness increase in smoked sirloins causes increase in shear force value $(r=0.348)$.

According to Dolata (2002) the fat in meat products together with protein and water influence the quality of meat in an essential way. It shapes rheologica values of filling, texture of ready product, its tastiness and juiciness. Essential fat decrease in the recipe of cured meat products causes the product to become empty in terms of taste and its texture to become more stiff, gummy and floury. The replacement of that element by potato fibre does not cause the improvement
Table 2 Correlation coefficients between texture parameters, and chemical composition and shear force of smoked sirloins

\begin{tabular}{lcccc}
\hline Specification & Fat & Protein & Water & Shear force \\
\hline Hardness 1 & 0.242 & -0.181 & $-0.256^{*}$ & 0.193 \\
Hardness 2 & $0.255^{*}$ & -0.188 & $-0.260^{*}$ & 0.191 \\
Adhesiveness & 0.137 & -0.160 & -0.132 & 0.203 \\
Cohesiveness & $0.487^{*}$ & $-0.447^{*}$ & $-0.446^{*}$ & 0.096 \\
Springiness & 0.083 & -0.062 & -0.091 & $0.348^{*}$ \\
Gumminess & $0.389^{*}$ & $-0.317^{*}$ & $-0.378^{*}$ & 0.143 \\
Chewiness & $0.367^{*}$ & $-0.297^{*}$ & $-0.354^{*}$ & 0.139 \\
Resilience & 0.093 & -0.056 & -0.041 & -0.213 \\
\hline
\end{tabular}

*- coefficients significant at the level of $\mathrm{p} \leq 0.05$

According to Wood's et al. (2004) research conducted on cured meat product the juiciness, tastiness and texture of studied products are strongly related with 
the fat content. Miller (2004) states that the increase in meat tenderness is positively correlated with mid muscle fat content because fat is softer than muscle fibres. Moreover, it protects fibres against fast thermal denaturation and it stops water in meat, thus improving tenderness of heated meat. In studies of that author correlations determined between fat content and TPA hardness and cutting strength were: $r=-0.63$ and $r=-0.30$ respectively, regardless of whether fat was marked in raw meat, or in heated one. Caine $\boldsymbol{e t}$ al. (2003) stated that springiness and resilience are strongly connected with the content of intramuscular fat However, in the studies of Zając et al. (2011) the correlation between the fat content and springiness was not confirmed. On the other hand, the relation between its amount and springiness $(r=-0.41)$, cohesion $(r=-0.42)$ and chewiness $(\mathrm{r}=-0.61)$ were stated.

Żochowska-Kujawska et al. (2010) observed that increasing water participation in the filling caused a decrease in hardness, gumminess and modules of springiness and viscosity, and the increase in cohesiveness, adaptability and thermal discharge of sausages made from boars' slight meat. On the other hand, increasing fat addition to filling caused a decrease in hardness, cohesiveness, gumminess and modules of springiness and viscosity, and increase in the plasticity of these sausages.

\section{CONCLUSION}

Many statistically significant $(\mathrm{p} \leq 0.05)$ correlation coefficients were stated between instrumentally marked texture parameters of smoked sirloins. Moreover the majority of those correlations were at a considerable and high level. A statistically negative and significant correlation coefficient was observed only between adhesiveness and resilience. The increase in water and protein content in smoked sirloins was most frequently connected with decrease in values of majority instrumentally marked texture parameters of these products. However, the stated correlations were at the medium level. On the other hand, the increase in fat content in smoked sirloins was connected with an increase in cohesion, gumminess, chewiness and hardness of these products. With an increase in resilience of smoked sirloins there also increases the value of their shear force.

\section{REFERENCES}

Biller E. (2013). Wpływ wybranych cech surowca na wskaźnik zbrązowienia teksturę modelowego wyrobu pieczonego z mięsa mielonego. Żywność. Nauka.

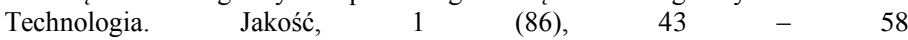
http://dx.doi.org/10.15193/zntj/2013/86/043-058

Bourne M.C. (2002). Food texture and viscosity: concept and measurement Second Ed., Food Sci. Technol., Inter. Series, Acad. Press, New York http://dx.doi.org/10.1016/b978-012119062-0/50006-1

Caine W.R., Aalhus J.L., Best D.R., Dugan M.E.R., \& Jeremiach L.E. (2003). Relationship of the texture profile analysis and Warner-Bratzler shear force with sensory characteristics of beef rib steaks. Meat Sci., 64 (4), 333-339. http://dx.doi.org/10.1016/s0309-1740(02)00110-9

Chang H.J., Wang Q., Zhou G.H., Xu X.L., \& Li C.B. (2010). Influence of weak organic acids and sodium chloride marination on characteristics of connective tissue collagen and textural properties of beef semitendinosus muscle. Journal of Texture Studies, $41 \quad$ (3), 279-301. http://dx.doi.org/10.1111/j.1745 4603.2010.00226.x

Cierach M., \& Gral R. (2005). Tekstura i barwa wybranych przetworów mięsnych z dodatkiem transglutaminazy. Inżynieria Rolnicza, 9 (69), 19-26.

Dolata W. (2001). Wpływ warunków kutrowania surowców mięsnych i tłuszczowych na jakość farszów i wędlin. Mięso i Wędliny, 3, 26-30.

Dolata W. (2002). Wpływ częściowego zastapienia tłuszczu błonnikiem ziemniaczanym na kształtowanie jakości farszów i drobno rozdrobnionych produktów mięsnych. Technologia Alimentaria, 1 (2), 5-12.

Dolatowski Z., Stasiak D., \& Pisarek S. (2003). Badania właściwości reologicznych oraz oceny sensorycznej modelowego wyrobu mięsno-owsianego o walorach dietetycznych. Technologia Alimentaria 2 (2), 67-75.

Dolik K., \& Kubiak M.S. (2013). Instrumentalny test analizy profilu tekstury w badaniu jakości wybranych produktów spożywczych. Nauki Inżynierskie i Technologiczne, 3 (10), 35-44. http://dx.doi.org/10.15611/nit.2013.3.03

Duda Z. (1998). Technologia mięsa w perspektywie początku XXI wieku wybrane zagadnienia. Gospodarka Mięsna, 12, 46-51.

Górecki T. (2011). Podstawy statystyki z przykładami w R. Wydawnictwo BTC Legionowo.

Guzek D., Głąbska D., Pogorzelska E., Pogorzelski G., \& Wierzbicka A. (2013). Instrumental texture measurement of meat in o laboratory research and on a production line. Adv. Sci. Technol. Res. J., 7 (19), 5-11. http://dx.doi.org/10.5604/20804075.1062329

Juszczak L. (2005). Tekstura żywności. Laboratorium Przemysłowe, 2, 40-44.

Makała H., \& Olkiewicz M. (1999). Kształtowanie tekstury produktu mięsnego. Przem. Spoż., 54, 47-49.

Marzec A. (2008a). Tekstura żywności. Część I - Wybrane metody instrumentalne. Przem. Spoż., 2 (62), 12-15.

Marzec A. (2008b). Tekstura żywności. Część II - Wybrane metody sensoryczne. Przem. Spoż., 5 (62), 42-45.
Miller R. K. (2004). Palatability, Encyclopaedia of Meat Sciences, Elsevier Ltd. Nielsen P. M., (1995). Reactions and potential industrial applications of $\begin{array}{llll}\text { transglutaminase } \quad-\text { Food } \quad \text { Biotechnology, } & 9 & \text { (3), } & 119-156\end{array}$ http://dx.doi.org/10.1080/08905439509549889

Ostoja H., \& Cierach M. (2001). Kształtowanie tekstury mięsa wołowego. Inżynieria Rolnicza, 10(30), 261-268.

PN-ISO 11036. (1999). Analiza sensoryczna - Metodologia - Profilowanie tekstury. PKN. 1-22.

Ruiz de Huidobro F., Miguel E., Blazquez B., \& Onega E. (2005). A comparision between two methods (Warner-Bratzler and texture profile analysis) for testing either raw meat or cooked meat. Meat Science, 69 (3), 527-536. http://dx.doi.org/10.1016/j.meatsci.2004.09.008

Szczepańska K., \& Dolik K. (2012). Ocena tekstury żywności wybrane metody mechaniczne. Przem. Spoż., 5 (66), 38-42.

Wood J.D., Richardson R.I., Nute G.R., Fisher A.V., Campo M.M., Kasapidou E., \& Sheard, P.R. (2004). Effects of fatty acids on meat quality: a review. Meat Science, 66 (1), 21-32. http://dx.doi.org/10.1016/s0309-1740(03)00022-6

Zając M., Midura A., Palka K., Węsierska E., \& Krzysztoforski K. (2011). Skład chemiczny, rozpuszczalność kolagenu śródmięśniowego i tekstura wybranych mięśni wołowych. Żywność. Nauka. Technologia. Jakość, 4 (77), 103 - 116 http://dx.doi.org/10.15193/zntj/2011/77/103-116

Zhu Y., Rinzema A., Tramper J., \& Bol J. (1995). Microbial transglutaminase - a review of its production and application in off processing- Appl. Microbiol. Biotechnol, 44, (3-4), 277-282. http://dx.doi.org/10.1007/bf00169916

Żochowska-Kujawska J., Lachowicz K., Sobczak M., Gajowiecki L., Kotowicz M., Zych A., \& Oryl B. (2010). Wykorzystanie mięsa z dzików do produkcji modelowych kiełbas drobno rozdrobnionych ze zmiennym dodatkiem wody thuszczu. Żywność. Nauka. Technologia. Jakość, 2 (69), 29 - 39. http://dx.doi.org/10.15193/zntj/2010/69/029-039 